\title{
Islamic Identity in the Canadian Multicultural Context
}

\author{
Abdullah Omar \\ Independent Education Consultant \\ Omara639@gmail.com
}

\begin{abstract}
This paper aims to explore aspects of Islamic identities in the Canadian multicultural context. It argues that Islamic identities face challenges in the Canadian liberal multicultural context, largely because multiculturalism in Canada was initially designed for well-integrated European ethnic groups and it may not have been intended to foster Islamic identity. Further, some Muslims have a significant problem with a multiculturalism that marginalizes religious beliefs and values in favor of secular inclusiveness. The paper presents the core elements of Islamic identities as well as the challenges of external pressures. It notes that while Islamic identities are anchored firmly on the concept of Ummah, Muslims may develop multiple affinities, which adds another dimension to the Canadian mosaic. The paper recommends accommodating faith communities, including Muslims meaningfully. It invites Muslims to join the multicultural conversation with a genuine Islamic voice. Further, it encourages the Muslim community to respond to the negative image effectively.

Many Western societies have been grappling with the position of Islam and its symbols in a multicultural public space. As recently as December 12, 2011 Canadian Citizenship and Immigration Minister announced that Muslim women who wear niqabs must remove the cover when they are becoming citizens (Mackrael \& Perreaux, 2011). In November 29, 2009, 57.5 percent of the Swiss populace voted to ban the building of new minarets in their country. The ban caused a stir around the world. Governments, human rights groups, and individuals around the world condemned the ban. UN human rights chief, Navy Pillay labeled this action as discriminatory and deeply divisive (Klapper, 2009). A French parliamentary panel recommended the banning of Niqab or Burqa, (a head to toe outer cover, including the face with an opening for the eyes) in schools, hospitals, public transportation, and all government offices. This followed banning girls from wearing the hijab in the French public school system.

This paper is an attempt to discuss Islamic identities within the Canadian Multicultural context. The first section of the paper introduces Canadian Multicultural debates and its relation to Islamic identities. The second section defines identity and examines its markers, importance and multiplicities. Identity was defined here and explained according to Taylor's concept of essential selfhood. I expanded on the concept using works by Merry (2008) and Monshipouri (2009). The third section introduces Islamic identity; it explores its fundamental elements and some of the challenges Muslim communities face in fostering and maintaining this identity.

Liberal multiculturalism promotes religious freedom, and liberal democratic states protect religious practices. The promotion and the protection are built upon a view that speaks to the issues of minorities from a secular vantage point. As Azmi (2001) argues, it
\end{abstract}

Cultural and Pedagogical Inquiry, 2011, 3(2), pp.16-29

ISSN 1916-3460 @ 2011 University of Alberta

http://ejournals.library.ualberta.ca/index.php/cpi/index 
fails to "speak to the issue as viewed from the ideological vantage point of religiously motivated minority communities" (p.270). Minorities apparently get along with the system as long as they conform to the Western secular understanding of religion, which relegates it to the private, personal realm.

This discourse, however, hardly accommodates the needs of ideologicallymotivated but diverse religious minorities who feel that the current liberal multiculturalism and its educational institutions tend to marginalize their values and beliefs. This perhaps explains the rapid growth of Islamic institutions even in the provinces that do not provide any financial support to independent schools. Consequently, some Muslim groups strive to find alternatives that include Islamic educational institutions.

The apparent reluctance of some Muslims to embrace liberal multiculturalism does not mean that Muslims are hostile to multiculturalism, for the Muslim community itself is very diverse and multicultural. However, as Azmi argues (2001), some "Muslims have significant problems with liberal multiculturalism that directs them to marginalize religious values and beliefs in favor of secular inclusiveness. A multiculturalism that includes the outlook of faithful Muslims would need to allow the explicit retention of religious values and beliefs, even when these run contrary to prevailing public norms" (p.271). For these groups, Islam is the standard, against which all other ideas and values must be measured. This is in line with a generally accepted Islamic view that maintains that clear evidence from the Qur'an and the Sunnah overrides all other views, regardless of their source. This is not to say that Muslims and their educational institutions are against multiculturalism, but they may require a kind of multiculturalism that provides adequate space for Islamic identities and values.

\section{Canadian Multiculturalism, the Context}

Multiculturalism is considered a set of policies and practices that promotes attention to and representation for various groups and communities who want to maintain a certain level of distinction for their cultures and identities (Cashmore, 1996; Modood, 2007). Multiculturalism in this sense is a response to multiple systems and communities who share social space but espouse different convictions and values. Ideally, multiculturalism would foster a harmonious coexistence among diverse cultural, racial, ethnic and religious entities in a pluralistic society. Canadian multiculturalism and multicultural policies in particular, is not without critics. Some of these critics are against the idea of multiculturalism, while others disagree with the type of multiculturalism which Canada adopted.

The multiculturalism critics argue (Bibby, 1990; Gairdner, 1990; Bissondooth, 1994) that multiculturalism compromises national unity; it encourages narrow loyalty among ethnic groups, which condemns the minority groups in life of perpetual isolation, which leads only to economic and political disadvantage. Some of the critics (Gairdner, 1990) extend the danger of isolation to argue that multiculturalism will eventually destroy English Canada by undermining the core values and customs, which are the foundations of the nation's stability.

Canadian multiculturalism also faces contestation from within. The critics include Anti-Racism, Feminist perspective, as well as some liberal multiculturalists. Anti-Racism 
perspective, for example, asserts that Canadian multiculturalism does not address systemic marginalization and inequalities. Accordingly, Canadian multiculturalism falls short of causing real structural change because it does not interrogate power effectively. As Dei (2000) argues, Canadian multiculturalism promotes values such accommodation, appreciation, commonality and goodwill. However, this is based on an assumption that "we start from a relatively level playing field that we have access to similar resources and we have comparable values, aspirations and concerns. Nothing could be further from the reality of those racially minoritized in our communities" (p.304).

Some feminist researchers also critique liberal multiculturalism in terms of giving special rights to minority groups. They argue that assigning special rights and privileges to these groups often perpetuates gross gender inequalities. According to Susan Okin (1999), liberal multiculturalism of minority rights has two major downfalls. First, liberal multiculturalism ignores the private sphere, which is an essential base for any culture. She argues that advocates of many cultures may not openly impose their illiberal beliefs and practices on others. In fact, they may appear to respect women and girls' civil and political rights in public. However, "many cultures do not, especially, in the private sphere, treat them like anything, like the same concern and respect with which men and boys are treated or allow them to enjoy the same freedom" (p.21). Second, multiculturalism treats all multicultural groups as a monolithic entity. It pays little or no attention to the fact that these minority groups are gendered and there is a substantial power inequality between men and women.

Conversely, multiculturalism proponents (Kymlicka, 1998; Dion, 2000; Magsino, 2000; Adams, 2007), argue that, contrary to the critics' claims, Canadian multicultural policy encourages integration and healthy cultural encounter rather than isolation and marginalization. The policy clearly aims to create a platform that accommodates all Canadians. As Dion (2000), argues, the policy meant "to help Canadian citizens to develop and flourish. It in no way weakens the feeling of common Canadian identity. On the contrary, Canadians' acceptance of their plural identity nourishes with them a genuine love for their country" (p.95). Romulo Magsino (2000) agrees with Dion and argues further that Canadians are not only diverse in their racial and ethnic backgrounds but also in their beliefs, values and customs. Hence, rather than attempting to assimilate or marginalize minoritized groups, Canadians should seek unity by embracing respect, tolerance and acceptance through multiculturalism.

Canadian multiculturalism is founded on the liberal conception that poses challenges to some communities who do not share the philosophical underpinnings of this theory. This is so because multiculturalism in Canada was initially designed for wellintegrated European ethnic groups (Kymlicka, 2006) and the debates about multiculturalism were driven by Ukrainians, Italians, and other European immigrants in the 1960 s and 1970 s.

Multiculturalism in Canada may not have been intended to facilitate the integration of the Muslim community or accommodate Islamic education and its institutions, nor was multiculturalism meant to eliminate the challenges that Muslims and similar minority groups face.

According to Taylor (1994) and Yusuf (2000), liberal multiculturalism adopts and universalizes a Christian perception of religion that separates the sacred from the mundane. In this case, Yusuf further argues that "religious freedom becomes merely the 
freedom to conform to another society's perception of what religion entails" (2000, p.32). To Yusuf and others (Meer, 2007; Modood, 2007; Taylor, 1994), religious minorities like Muslims, who offer a different worldview on the nature of religion and education, may have trouble with, and pose a challenge to, the current multicultural system.

There is an ingrained and acknowledged privileging of the majority's history, values, and language. The Canadian system, as Kymlicka describes (2001), appears neutral on the surface, while favouring the dominant groups. Kymlicka (2001) acknowledges that, "it is the majority language that is used in public institutions; the majority holidays that are recognized in the public calendar; the majority history that is taught in schools" (p.43). The minorities' request for group-specific rights therefore, is a reasonable demand to mitigate these unfair arrangements.

\section{Identity}

As Kymlicka (2001) articulates, Canadian Multiculturalism provides a plate for minority groups through which they are able to request group specific rights. Promoting and protect identity is central to these group rights.

\section{Defining Identity}

The identities of an individual or a group of people are essentially described as a set of characteristics that an individual or groups of individuals recognizes their own, or what makes them different or unique. The characteristics, which render an individual or group as unique, include their core values, beliefs and convictions that structure their lives. These properties form a core personality that gives meaning to a person's selfunderstanding in various contexts (Monshipouri 2009; Merry, 2008 Abdi \& Ghosh, 2004; Maalouf, 2003). To Monshipouri (2009, pg. 4), identities create a measure of inclusion and exclusion, which defines a social 'we' to delineate and mark the boundaries against the 'other'. These unique properties, be they individual's or groups' are what Charles Taylor characterizes as an 'essential self'.

Identities are defined as "the interaction of person's self-conception with how others conceive her: identities are the understandings we have of ourselves and others" (Nelson, 2001, pg. 6). This is to say that identities combine the personal or the inner world with the collective and cultural realm (Monshipouri, 2009; Merry, 2008). Identities, therefore, relate to self- understanding, self-esteem and self- reflection on the one hand and how others understand, judge and value that self-conception and its manifestations.

Taylor (1989 and 1994) offers an insightful analysis that helps explain the nature of what he calls 'essential self/identity', its formation and politics. He eloquently connects "selfhood" or identity to the definition of the good. Identity, to him, is a moral issue that is embedded in our answers to the essential question: "What makes our lives meaningful?" Alternatively, "What makes life worth living?" To this end, Taylor situates selfhood in the realm of morality. He considers selfhood not only an inner component of our personal characteristics, but a major contributing factor that shapes our perception of both self and the world. As he explains (1989), "Our style of movement expresses how we see ourselves as enjoying respect or lacking it, as commanding it or 
failing to do so" (p. 15). In other words, identity is what constitutes a person's self perception both as an individual and also as a member of a group.

From the standpoint of identity as a moral issue, Taylor introduces the notion of politics of recognition, which could be viewed as both a complement to and consequence of selfhood. That is, if selfhood or identity is a characteristic that uniquely belongs to an individual or a group, and if this characteristic defines the good life for the individual or the group, then all attempts to eliminate this characteristic and its manifestations are immoral and unacceptable. Instead, unique identities should be recognized, accepted, and celebrated.

This is to say that rather than searching for universal rights for individuals, Taylor's politics of recognition (1994) states that "what we are asked to recognize is the unique identity of this individual or group, their distinctiveness from everyone else" (p.82). To Taylor, recognition of the varied identities of individuals and groups is what makes liberal multicultural societies unique, because of the way they treat minorities and the rights they accord to them, including minorities who do not share in the definition of good. Taylor further argues that, first, any culture that provides meaning for diverse individuals with different needs and characteristics over a long period of time deserves admiration and respect even if this culture contains certain elements that others may object to or disagree with. Second, individuals and groups have the potential to form and define their own identities. However, societies also shape identities by the cues they give to individuals and groups.

\section{Marginalizing Identities}

Our identities are shaped by others because we need the recognition of others in order to be (Butler, 1997). Indeed, our own actions are a reflection of the cues that we receive from others. As Taylor argues (1989), "the very way we walk, move, gesture or speak is shaped, from the earliest moment, by our awareness that we appear before others, that we stand in a public space, and this space is potentially of respect or contempt, of pride or shame" (p.15). Hence, one's identity is, in part, subject to the approval of others; to be deprived of others' approval and /or appreciation is to be denied the chance to function meaningfully in one's own society. In other words, not recognizing or denying individual and group identity distorts that particular individual or group's self image and causes real damage.

Max Depree (1992) illustrates this deprivation of recognition by recalling his personal experiences at the Phoenix hotel: Whenever he went to the hotel's restaurant, one of the mannered hostesses took his orders, politely asking him the same question, "How many?" However, on one of his visits to the hotel, his knees gave away and he ended up in a wheelchair. Next morning, he went to the restaurant, but this time his wife was pushing the wheelchair. The hostess came and carefully passed by Mr. Depree and asked his wife politely, "How many?" Then, without looking at him, asked his wife, "Would he like to sit at the window?" Depree (1992) insightfully observes, "I had disappeared. In a twinkling, this polite, well-meaning young woman had stripped me of identity and position. It made me realize that to be oppressed is wrong, but to be overlooked may be even worse" (p.54). Mr. Depree had a considerable power and agency at his disposal. He was the chairman of the board of directors of Herman Miller, a primary innovator in the furniture business and one of the top twenty-five firms on the 
Fortune list of the most admired companies in the United States of America. Yet, it was a painful experience for him to be ignored even in a trivial setting.

Considering the power of individual groups' need for, and vulnerability to labelling, "non-recognition and/or misrecognition can inflict harm and literally constitute a form of oppression that incarcerates people in a false, deformed and existentially reduced mode of being" (Abdi \& Ghosh, 2004, pg. 27). Hence, Amin Maalouf's (2003) strong language is perhaps understandable in his description of some Muslim communities around the globe when he writes: "They are living in a world which belongs to others, and obey rules made by others, a world where they are orphans, strangers, intruders or pariahs" (P.75). They feel so because almost everything they see belongs to others; history, language, heroes, even what constitutes a good name, belongs to the dominant culture and its beneficiaries. While a particular group may feel excluded, isolated, or targeted, as Maalouf points out, finding pure and exclusive identity is hard, if not impossible. However, identities are neither particularly singular nor fixed and stable.

\section{Multiple Identities}

There are always multiple and overlapping identities. Each individual possesses and remains loyal to multiple identities. From the minute that we come into this world, we are subject to multiple identities, and with the exception of a few physical characteristics that we are born with, our identities continue to be ever incomplete and open to modification or expansion. Over the course of our life we may ignore or abandon certain aspects of what we consider to be important elements of our identities. The elements or markers include religion, nationality, social location, or gender, to name a few.

These identity markers often coexist without major problems. The situation may change, however, when these markers come into conflict. As Grant (1997) explains markers of multiple identities "may sometimes conflict, but this is not a necessary feature of multiple identities except when the forces behind any of the markers demand complete and unconditional loyalty" (p.14). In dealing with multiple identities, experiencing a certain level of tension, and even making some tradeoffs, is expected and considered normal in one's daily life.

One could ask whether I am a Muslim first, or a Canadian, or East African, etc., Tariq Ramadan (2010) considers this a bad question, and I agree with him. To Ramadan, the question explicitly addresses the person's identity, but it also implicitly questions the individual's loyalty. He describes these questions as meaningless because they are based on an oppositional definition of identity. Ramadan further argues that:

There are different orders within which one will have to define oneself differently. Asking whether one is primarily Muslim or American, Australian, Italian, French or Canadian opposes two identities and affiliations that do not belong to the same realm. In the realm of religion and philosophy, that which imparts meaning to life, a human being is first and foremost an atheist, a Buddhist, a Jew, a Christian or a Muslim: her or his passport or nationality cannot answer the existential question. When an individual must vote for a candidate at an election, she or he is first an American, Italian, French or British citizen involved in national affairs. Depending on the realm or the field of activity, the individual 
therefore puts forward one identity or another, and that is not contradictory (pp. 36-37).

In other words, every individual carries more than one identity, and he or she gives priority to one of these multiple identities according to the environment or the social setting. To further illustrate this point, Ramadan presents this telling example when he says, "You are a poet and a vegetarian. If you are a dinner guest, this is no time or place to insist on your identity as a poet, while if you attend a poetry circle, you are certainly not going to introduce yourself as a vegetarian" (p.37). Hence, while defining identity in terms of difference or uniqueness is considered a natural reaction, particularly during upheaval, this approach could lead to a confusing situation in which people's identities are reduced to a singular element, which opposes other essential components of the individual's identity.

\section{Islamic Identity}

The word "Islam" means both peace and submission. A Muslim, therefore, is a person who submits to his or her Lord peacefully. This submission requires declaring the testimony of the faith, which translates to: There is no God but Allah, and that Mohammed is the last messenger of God. Bearing witness to or declaring this testimony is a key to the Islamic faith. It also introduces a worldview and identity that is shaped by Islam. This worldview provides a ground of unity for Muslim communities. At the same time, it may pose challenges in forming and fostering a Muslim identity in multicultural, predominantly secular societies.

\section{Core Elements of Islamic Identity}

The concept of Shahadah (testimony of faith) is a fundamental principle of Islam. The Shahadah is a declaration of faith that is not only a personal issue but also has a social implication for accepting the teachings of Islam, which means joining the Ummah, the nation or community, of Islam. The Shahadah constitutes the purest expression of Islamic identity. The Shahadah both forms and informs Muslim identity (Ramadan, 2004). It regulates not only the spiritual, but also the social aspects of the believer's life, regardless of which sect he or she may belong to, or which attitude of practice he or she may adapt. As Ramadan (2004) explains, "Muslim identity at the central pivot is... faith, practice and spirituality" (p.79). This means that a Muslim identity is founded on faith and the practices of certain teachings. However, manifestations of this faith-based identity can also be found in the cultural expressions of Muslim communities.

Expressions such as: "Assalamu Alaikum," a greeting meaning "Peace be upon you," are universal among Muslims. "Bismillah," or "In the name of God," when starting anything, is a common preface to any declaration. "Alhamdulillah," means "thanks to God," a phrase used if someone is responding to a greeting or whenever one accomplishes a task. "Insha Allah", or "God willing", is said when referring to a future undertaking. These terms and many others go beyond race, ethnicity, nationality and even one's level of faith, practice, or tendencies towards traditionalism, fundamentalism, and modernism. These phrases are all in Arabic. However, they are now part of the Muslim lexicon and generally are used by Muslims all over the world irrespective of what 
language they speak. Some may use the Arabic version while others may translate to their local languages. However, they all understand what is meant by the terms.

As principal of an Islamic school, I serve students whose parents come from more than 30 different countries, and in this capacity I meet with many newcomers. The new immigrants often come to my school with interpreters. I listen to them through interpreters, yet I hear these phrases and others, equally familiar, punctuating their speech. They may speak Mandarin, Hausa, Turkish or Serbo-Croatian, but in addition to the faith and common practice they share a common vocabulary that expresses the faith and collective practices. This collectivity constitutes an essential self for Muslims regardless of race, ethnicity, or national boundaries.

Ramadan (2004) explains identity by introducing the concept of Ummah as a basic identity marker for a transnational community of believers. Ummah literally means a group, a community, or a set of belief within a group. It refers to an ideological community (Ramadan, 2004) that shares religious beliefs and ethical values as their primary frames of reference. Ideally, the concept of Ummah presents a connection that goes beyond ethnicity, race, or national boundaries without eliminating these other markers.

Islam offers a common vocabulary and collective practice. However, it is not and has never been a culture of its own, but it has fostered and given rise to a range of cultures (Hellyer, 2006;). It provided guiding principles and ethical parameters. Islam influenced these cultures immensely, but it was also enriched by them. As Abd Allah argues (2006), "sustained cultural relevance to distinct peoples, diverse places and different times underlay Islam's long success as a global civilization" (p.357). The adaptability to changing times and places enabled Islam to preserve principles while still showing flexibility to the ever-changing contexts. To this end, Islam's fundamental principles were likened to a crystal clear river with pure, life-giving waters that have no color of their own, but reflect the bedrocks over which they flow. The flowing waters connect different parts of the land (the Ummah). The (waters) also provide sustenance (spiritual and ethical guidelines).

The flowing waters may change certain aspects of the landscape, but will never eliminate the basic foundation of the land. To give an example, Islam has spread and still spreads across the globe. However, the culture of the first generation of Muslim has not. Islam has become an indigenous/local religion for the Indians who accepted as the case has been for the Senegalese and the Bosnians. This is to say that rather than exporting a particular culture, Islam provided "a process by which cultures were filtered or adjusted but never entirely banished by Islam" (Hellyer, 2006, pg. 336). Even though Islam eradicated certain aspects of the Arabian culture, which in turn, contradicted or went against the Islamic principles, it also adapted, and actually encouraged, various practices and traditions of the Arabian people.

By filtering or adjusting cultures, Islam paves the way for integrated cultures and identities that are governed by its principles but rooted in the indigenous ways of doing things. As Abd Allah explains (2006), "a culture is successful when it imparts an operative identity, produces social cohesion and gives its members knowledge and skills that empower them to meet their individual and social requirements effectively" (p.360). Consequently, a key measure for a successful culture is the capacity to impart a sense of self, where individuals are comfortable with their own personal identities. Equally 
important, culture also satisfies the sense of belonging to a social unit. Adjusting cultures and integrating them to Islamic values is one way of satisfying this need.

As mentioned earlier, Islam provides a collective sense for its followers through the membership to the Ummah. This (at times) imaginary community is not bound by geographical location, historical chapter or ethnic attachment. Ummah, in this context is a diasporic construct that psychologically binds Muslims to an ideal community of believers. Having affinity towards the Ummah is part of the Islamic faith as mentioned earlier. However, this feeling has been accentuated by a number of reasons, including improved worldwide communications, major international incidents in and around the 'Muslim world' and an overall disillusionment with post colonial national states. Hence, a significant number of contemporary Muslims and particularly the youth, no longer feel connected to a national state or an ethnic group (Abd-Allah, 2006; Hellyer, 2006). Instead, they strive to strengthen their ties to the larger Muslim communities around the world while endeavoring to cultivate a healthy relationship with the local context.

The emphasis on Ummah has its foundations in the Islamic sources (the Qur'an and the Sunnah). However, and perhaps equally important, the concept is often employed in response to both internal and external pressures, which face Muslim communities. Ummah in this context is used as a resource to combat prejudice, stereotypes and other forms of maltreatments against the Muslim individuals and communities (Merry, 2008). The concept is also used to overcome internal conflicts within the Muslim community. As Monshipouri argues (2009), many Muslim organizations see in the concept "an opportunity to bypass their ethnic and national cleavages and to create something closer to what an Ummah (community) should be. This perceived rather than real community, demonstrates that global Muslim identity has meant delinking Islam from any given culture in favor of a transnational and universal set of specific patterns (p.24). Organizations such Islamic Society of North America (ISNA) and Islamic Circles of North America (ICNA), among many others, illustrate this trend.

\section{Unity within Diversity}

While it is true that Islam provides Muslims with a unique system that caters to all aspects of life, it is also true that followers of the faith are highly diverse individuals and groups that sometimes appear to be very different in all aspects of their beliefs and behavior. In addition to their racial, national and ethnic differences, Muslims also belong to different theological sects. Even if they identify themselves as belonging to one sect (i.e. Sunnah or Shi'ah), followers within that sect may differ in the jurisprudential school of thought that they follow.

Muslims also differ in the ways they practice Islam and how they respond to modernity. Some researchers (e.g. Lawson, 2005) classify Muslims into three tendencies, namely fundamentalist, traditionalist, and modernist. The fundamentalist approach attempts to keep Islam in its purest form. This group makes a concerted effort to protect Islamic teachings from external corruptions (such as celebrating Christmas or other religious practices) and internal corruptions (such as introducing new acts of worship or performance of Islamic rituals in a new way) by eliminating all alien or innovative practices in Islamic rituals. Their goal is to ensure that Islam is taught and lived in its purest form without much consideration for the larger society's cultural norms or local 
customs. They attempt to stop, or at least minimize, outside influences on Islamic practices.

The traditionalist approach allows a slow process of change and adaptation. This process is generally guided by Islamic principles, but tends to mix Islam with ethnic, national, or traditional cultures. This form of Islam, according to Saeed (2009), "is largely ethnically based, coloured by Islam from 'back home'. Its focus is, primarily, on basic rituals such as prayer and fasting as well as Islamic practices brought from places of origin" (p.209). In fact, some of these communities are connected to their original homeland more than they are connected to the Muslim community of Canada. They often send their children back home, and import religious leaders and religious learning resources from their countries of origin.

The third group, modernists, adopts a loose interpretation of Islam. Their goal is to establish indigenous Islam within the secular multicultural society. While loyal to the basic tenets of the faith, modernists give themselves a large margin of freedom to reinterpret certain aspects of Islam. They are not often attached to a particular school of thought, theological group, or any transnational Islamic movement (Saeed, 2009). In general, they do not subscribe to the notion that Islam is a comprehensive way of life. Rather, they view Islam as a spiritual and ethical source that provides guidance in how one should relate to Allah and His creation.

It is important to note, however, that these tendencies do not constitute theological sects or jurisprudential schools of thought. In fact, a "Muslim may hold all three types of attitude, depending on different situations in life" (Lawson, 2005, pg. 7). Further, the internal diversity among Muslim communities may negatively affect but it does not eliminate the unified Islamic identity. As Monshipouri argues (2009), "whether Muslims identify themselves as Wahabis, Tablighis or Salafis, Militants or reformists, they all are part of a process to recast Muslim identity in a different light, one that is not attached necessarily to a particular culture or territory" (p.17). Therefore, despite their variations or tendencies, they all have a claim to the Islamic identity in their own ways.

Muslims in Canada come from a set of diverse racial, linguistic, ethnic and national origins. They experience Islam in different settings and circumstances, and some of them bring with them practices and interpretations that are sometimes unique to their particular background. These diverse experiences and interpretations often lead to fragmentation and sometimes internal conflicts within a diverse Islamic community, posing challenges to the community's collective efforts. While the communities show various levels of commitment to Islam and its universal principles, most of them, nevertheless come from postcolonial nation states, bringing with them their national and regional cultures, which in some cases conflict. These internal diversities are not as challenging as the external pressures, which face Muslim individuals and institutions in Canada.

\section{External Pressures and Muslim Identities}

Pressure on the Muslim community and its educational institutions has increased since September 11, 2001. Muslim communities and their institutions around the world became the focus of the media and law enforcement agencies after what is now commonly referred to as $9 / 11$. The global war on terror, in many cases, put Islamic institutions under constant scrutiny and confines a large number of Muslim communities to live under what could be described as psychological incarceration. 
Muslim individuals and institutions experience various degrees of difficulty in preserving their traditions and practicing certain aspects of their religion. Without minimizing some of the positive indications about how the Canadian population views its Muslim members, there are segments in the Canadian population that view Islamic educational institutions as a potential threat to national security.

Muslim schools have been blamed for teaching extremism, religious intolerance, militant theology, and even serving as a potential training ground for terrorism. Opponents of Islamic education in Canada express concerns about the possibility of these educational institutions becoming training grounds or recruiting centers for future terrorists who may collaborate with Canada's enemies, or plan attacks, targeting Canadians (Kymlicka, 2003). Some of the opponents of Islamic educational institutions actually urge Canadian law enforcement agencies to thoroughly review the Islamic Studies curricula of Canadian Muslim schools.

The poor and, at times, misguided, presentation of Islam and Islamic institutions in the media both accentuates and perpetuates general anxiety about the way of life of Muslims who outwardly express or practice their religion, as two recent controversies in Quebec illustrate. One example of these increased tensions involves Asmahan Mansour, an 11-year-old Muslim girl who was ejected from a soccer tournament simply for wearing a hijab. In another example, a group of girls in Montreal were stopped from practicing Taekwondo while wearing the headscarf. Like Asmahan, these girls were members of a club, training and competing like the rest of the members (Adams, 2007). However, the girls were expelled from the competitions citing safety concerns. Further, despite allowing hijabi girls to past competitions, the Quebec Federation of Taekwondo insisted on the ban citing rules banning headscarves, jewelry or any other accessories worn by the competitor under the helmet.

\section{Conclusion}

This paper discussed some of the challenges, which Muslim communities face in their attempt to foster Islamic identity within the current Canadian multicultural context. In light of these challenges, I would like to conclude the paper with three key recommendations:

(1) Accommodating Faith Communities Effectively: Multiculturalism has been largely reduced to superficial activities, such as sharing ethnic food, exotic fashion fairs, and dance festivals et cetera. As a side effect, religious communities, particularly those who do not participate in these activities, are often marginalized. Multiculturalism should bring about incorporating both cultural and religious resources of minority groups, including Muslims to the national fabric. That is to say, rather than camouflaging certain groups' values as universal and relegating the rest to occasional dances and food exchanges; multiculturalism should accommodate faith communities and their values meaningfully.

(2) Responding to the negative image effectively: The first step is establishing an understanding that the anti-Muslim propaganda predates the current political conflicts. It is rooted in history, and often motivated by a combination of 
misunderstanding, fear and domination. Muslim communities need to address these issues internally and externally. This would include challenging Islamophobia and other forms of marginalization openly.

(3) Joining the multicultural conversation: This entails accepting multiple definitions for the meaning of the "good life". Celebrating distinctive cultures and identities is a way of encouraging the meaningful expression of these cultures and identities. This requires challenging the understanding of the dominant groups, which often tends to "put the onus on those who are different to cross the distance between their realities and dominant consciousness, while those who represent the norm avoid their responsibility" (Abdi \& Ghosh, 2004, pg. 26). Muslim communities need to join the multicultural conversation and make distinctive contributions rather than reacting to cultural and political actions of the dominant society's secular institutions. They need to promote an Islamic approach to multiculturalism that is based on learning from others, as well as, teaching others to create new possibilities. This approach acknowledges the common values, but it also urges people to recognize differences through mutual respect and spirit of "knowing to be known". The approach is rooted on a verse in the Qur'an that reads: "O mankind! Indeed, we have created you from male and female and made you into nations and tribes so that you may know one another---"(Qur'an: 49:13). Knowing one another entails joining the conversation without fear or hesitation. It requires being loud enough so the other can hear, but at the same time it requires being attentive enough to listen to other voices, and to respond appropriately. 


\section{References}

Abd-Allah, U. (2006). Islam and the cultural imperative. Cross Current, 56 (3), 357-375.

Ghosh, R. \& Abdi, A.A. (2004). Education and the politics of difference: Canadian perspective. Toronto: Canadian Scholars' Press Inc.

Adams, M. (2007). Unlikely utopia: The surprising triumph of Canadian pluralism. Toronto: Viking Canada.

Azmi, S. (2001). Muslim educational institutions in Toronto, Canada. Journal of Muslim Minority Affairs, 21(2), 259-272.

Bibby, R., (1990). Mosaic Madness. Toronto, Ontario: Stroddat Publishing.

Bissondaath, N. (1994). Selling illusion: The cult of multiculturalism in Canada. Toronto: Penguin Books.

Bouchard, G. \& Taylor, C. (2008). Building the future: A time for reconciliation. Retrieved December, 2009, from www. Accodments.qu/documentation/reports

Butler, J. (1997). Excitable speech: A politics of the performatives. New York: Routledge. Cashmore, E. (1996). Dictionary of race and ethnic relations. New York: Routledge.

Dei, G. (2000). Contesting the future: Anti-racism and diversity. In Nancoo, S. (Ed.), $21^{s t}$ Century Canadian Diversity. Mississauga: Canadian Editors' Press.

Depree, M. (1992). Leadership Jazz. New York: Dell Publishing Co.

Dion, S. (2000). Unity in diversity: The Canadian way. In Nancoo, S. (Ed.), $21^{\text {st }}$ Century Canadian Diversity. Mississauga: Canadian Editors` Press.

Grant, N. (1997). Some problems of identity and education: A comparative examination of multicultural education. Comparative Education, 33 (1), pp. 9-28.

Gairdner, W. (1990). The Trouble with Canada. Toronto, Ontario: General Paper Book.

Hellyer, H.A. (2006). Muslims and Multiculturalism in the European Union. Journal of Muslim Minority Affair, 26 (3), pp. 329-351.

Klapper, B. (2009, December 1). UN Slams 'Discriminatory' Swiss Minaret Ban. Retrieved from http://www.huffingtonpost.com/2009/12/01/un-slams-swiss-minaret-ba_n_374996.html.

Kymlicka, W. (1998). Finding Our Way: Rethinking ethno cultural relations in Canada. Don Mills ON: Oxford University Press.

Kymlicka, W. (2001). Politics in the vernacular: Nationalism, multiculturalism and citizenship. New York: Oxford University Press.

Kymlicka, W. (2003). Justice and security in the accommodation of minority nationalism. In Dieckhoff, A. (ed.), Nationalism, liberalism and pluralism. Lexington: New York.

Kymlicka, W. (2006). Testing the Bounds of the Liberal Multiculturalism. A paper presented at the Trudeau Foundation's Conference on Public Policy "Muslims in Western Societies" November 16, 2006).

Lawson, I. (2005). Leading Islamic schools in the UK: A challenge for us all. Retrieved July 17, 2006 from www.ncsl.org.uk

Maalouf, A. (2003). In the name of identity. New York: Penguin Books.

Mackrael, K. \& Perreaux, L. (2011). Muslim women must show faces when taking citizenship oath. Retrieved January 4, 2012 from www.globeandmail.com/news politics/muslim-women

Magsino, R. (2000). The Canadian Multiculturalism policy: A pluralist ideal revisited. In Nancoo, S. (Ed.), $21^{\text {st }}$ Century Canadian Diversity. Mississauga: Canadian Editors` Press. 
Mandeville, P. (2007). Islamic education in Britain: Approaches to religious education in a pluralistic society. In Henfer, R. \& Zaman, Q. (Eds.), Schooling Islam: The culture and politics of modern Islamic education. Princeton N: Princeton University Press.

Meer, N. (2007). Muslim schools in Britain: Challenging mobilisation or logical development? Asia-Pacific Journal of Education, 27 (1), pp. 55-71.

Merry, M. (2008). Culture, identity and Islamic schooling. New York: Palgrave Macmillan.

Modood, T. (2007). Multiculturalism, a civic idea. Cambridge: Polity Press.

Munshipouri, M. (2009). Muslims in global politics: Identities, interests and human Rights. Philadelphia, Pennsylvania: University of Pennsylvania Press.

Okin, S. (1999). Is multiculturalism bad for women? Princeton: Princeton University Press.

Ramadan, T. (2004). Western Muslims and the future of Islam. New York: Oxford University Press.

Ramadan, T. (2010). What I believe. New York: Oxford University Press.

Saeed, A. (2009). Muslims in the West and their attitudes to full participation, in Western societies: Some reflections secularism. In Levey, G. \& Modood T. (Eds.), Secularism, religion and multicultural citizenship. Cambridge: Cambridge University Press.

Taylor, C. (1994). The politics of recognition. In D. Goldberg (Ed.), Multiculturalism: A critical reader. Oxford: Blackwell Publishers.

Taylor, C. (1989). Sources of the self: The making of the Modern identity. Cambridge: Harvard University Press.

Taylor, C. (2009). Introduction. In Levey, G \& Modood, T (Eds.), Secularism, religion and multicultural citizenship. Cambridge: Cambridge University Press.

Yusuf, A. (2000). Islam, minority and religious freedom: A challenge to the theory of pluralism. Journal of Muslim minority affairs, 20 (1), pp. 29-41. 